This item was submitted to Loughborough's Research Repository by the author.

Items in Figshare are protected by copyright, with all rights reserved, unless otherwise indicated.

\title{
Tariff structures and incentives for water demand management
}

PLEASE CITE THE PUBLISHED VERSION

http://dx.doi.org/10.1680/wama.12.00120

PUBLISHER

(C) ICE Publishing

VERSION

VoR (Version of Record)

LICENCE

CC BY-NC-ND 4.0

REPOSITORY RECORD

Kayaga, Sam, and lan K. Smout. 2019. "Tariff Structures and Incentives for Water Demand Management". figshare. https://hdl.handle.net/2134/14499. 


\section{Tariff structures and incentives for water demand management}

Sam Kayaga MSc, PhD, CEng, MCIWEM

Senior Lecturer/Programme Manager, Water Engineering and Development Centre (WEDC), Loughborough University, Loughborough, UK
Ian Smout MSc, CEng, FICE, MCIWEM

Principal Programme Manager, Water Engineering and Development Centre (WEDC), Loughborough University, Loughborough, UK

Urban water managers need to adopt water demand management (WDM) as one of the ways to provide for the needs and demands of escalating urban populations, amidst the negative impacts of increased pollution loads and climate change on finite water resources. This paper reviews how urban water tariff structures could be designed to promote water conservation in households while also ensuring revenue sufficiency for the service providers and affordability for low-income households. As an example, the paper describes the case of Zaragoza (Spain), a city where implementation of a water-conserving tariff and providing economic incentives largely contributed to a $27 \%$ reduction in overall water consumption between 1996 and 2008, although the population of the city increased by $12 \%$. Similar principles were adapted to model a water-saving, socially equitable tariff for the city of Kampala (Uganda). The proposed tariff for Kampala can save over 2.5 million $\mathrm{m}^{3}$ of water and generate an extra US\$ 0.68 million of revenue per year, which could be used to extend water services to currently unserved households in low-income settlements. If implemented, the tariff could enhance economic efficiency, revenue sufficiency, social equity and service coverage.

\section{Introduction}

The world's population is escalating amidst fixed water resources. UN-Habitat projects the world's population to increase from about 6.9 billion in 2010 , to 8.3 billion in 2030 , with most of the growth in less developed regions. In the past three decades, the world has witnessed phenomenal urbanisation rates, with over half of the world's population living in towns and cities since 2008. Developing countries will experience higher demographic challenges, where it is estimated that the urban population will increase from 2.57 billion in 2010 to 3.95 billion by 2030 , representing $94 \%$ of the global urban population growth (UNHabitat, 2009). The combined effects of rapid urban growth and the predicted increase in negative impacts of climate change will inevitably result in a huge decrease in per capita water availability in urban areas of developing countries (Stern, 2007).

This looming water scarcity, coupled with widespread environmental degradation, has brought into focus the need for planned action to manage water resources in a more effective way. The existing challenges cannot be overcome through conventional urban water management principles, which are usually overdependent on supply planning. Increasingly, there is need for urban water managers and planners to adopt an integrated resource planning (IRP) approach. IRP is the process of carrying out a comprehensive analysis of both demand-side and supplyside options, using a common set of criteria, in order to deduce least-cost options for satisfying increasing demand (White and Fane, 2001). Demand management, an important component of IRP, may be defined as the development and implementation of strategies, policies, measures or other initiatives aimed at influ- encing demand so as to achieve efficient and sustainable use of a scarce resource (Savenije and van der Zaag, 2002).

Water demand management (WDM) involves the adoption of policies and investment by a water utility to achieve efficient water use both within the water distribution network and on the customers' side (Kayaga, 2011). Measures in the distribution network include

reduction in system losses, including timely leakage detection and repair

- efficient operational procedures such as optimum operating pressure and reduced mains flushing or reservoir cleaning

control of street water points

- institutional capacity building in the utility to raise the importance of WDM measures

- ensuring accountability of staff of the water utility (Kayaga, 2011; Turner et al., 2006; White and Fane, 2001).

As part of WDM measures, a water utility could also introduce universal customer metering to

- encourage economic usage of water

maintain efficient and informative billing systems

- design and enforce water tariffs that encourage water conservation in customers' properties

- provide comprehensive information, education, training and advisory services to customers who wish to take action to reduce their water use 
- provide detailed water use analysis (audits) for water consumers in the various sectors

- provide financial incentives for the purchase and installation of efficient water using equipment in customers' premises (Kayaga, 2011; Turner et al., 2006).

For water conservation to be sustainable, utilities need to tap into the conservation potential from both behavioural and technical categories and use a combination of measures and instruments that will achieve the optimum changes. Measures are actions to be taken - the conversion of inefficient to efficient flush toilets, for example. Instruments are how to ensure the chosen measures are taken up by the customers, for example through public education, advertising and marketing. Instruments may be economic, regulatory or communicative (Turner et al., 2006).

This paper focuses on how economic instruments can be used to manage water demand in end-users' premises. Economic instruments may be defined as '...the use of market-based signals to motivate desired types of decision-making. They either provide financial rewards for desired behaviour or impose costs for undesirable behaviour' (Cantin et al., 2005). Economic instruments use market-based signals to motivate desired types of decision-making, which may be in form of financial incentives or imposition of costs for undesirable behaviour, mainly through tariff structures (Kayaga, 2011; Turner et al., 2006).

The remainder of this paper is based on a study into the use of tariff structures and financial incentives for WDM. The study was carried out as part of an integrated research project funded by the European Union (EU), whose overall objective was to apply integrated water resources management concepts for the achievement of effective and sustainable urban water schemes in the 'city of the future (i.e. projected 30-50 years from now)'. The 5-year Switch (Sustainable Water management Improves Tomorrow's City Health) project aimed at developing efficient and interactive urban water systems and services in the city's geographical and ecological setting, which are robust, flexible and responsive to a range of global change pressures.

The next section briefly discusses the use of tariff structures for WDM. Section 3 details how tariffs and financial incentives have contributed to a successful integrated programme for enhancing a water-saving culture in the city of Zaragoza, Spain. Results of a model developed for applying an example of a water-conserving tariff in the city of Kampala, Uganda, are reported in Section 4 and conclusions are presented in Section 5.

\section{Using tariff structures for WDM}

\subsection{Objectives for setting water tariffs}

A tariff structure may be defined as a set of rules and procedures used to determine how to charge different categories of consumers. A tariff structure is an important management tool that determines the level and pattern of revenue

- contributes to the ability of the service provider to attract capital

- creates incentives with respect to the production and use of water services

- influences the total cost of production and value of the service delivered

- allocates costs among customers, groups of customers, and over time (Whittington and Boland, 2001).

The form of tariff structure will vary, depending on the objective(s) of the service provider. There are five main objectives that may be considered in the design of a water tariff (Barberán and Arbués, 2009; Whittington, 2003).

- Cost recovery or revenue sufficiency. The service provider needs to collect enough revenue that will cover operation and maintenance costs, cover repayment of loans to replace/ expand infrastructural assets, provide a return on capital employed and maintain a cash reserve for unforeseen circumstances.

- Equity. The allocation of costs among consumers should be proportional to obtained benefits. That is, consumers receiving the same benefits should pay the same costs (horizontal equity) and those receiving different benefits should pay different costs (vertical equity).

- Economic efficiency. Set prices send signals to consumers that encourage efficient use of the water resource.

- Poverty alleviation or affordability for the poor. The tariff structure should take consideration of poor communities and ensure that all households can afford basic water services for public health. This is an important factor for water utilities in developing countries.

- Simplicity. The tariff structure should be easily understood by customers. It should also be simple to administer and enforce on the part of the service provider.

Other objectives cited in the literature are fairness, public acceptability, political acceptability, enhancement of credit rating and net revenue stability. It is difficult to consider all the objectives in the design of a water tariff because some are conflicting and some are difficult to quantify (Barberán and Arbués, 2009). Hence there is no consensus on the best set of criteria for tariff design and, in practice, service providers emphasise different objectives. This divergence is fuelled by inadequate empirical data on what really works, partly due to the monopolistic nature of the provision of water services (Whittington, 2003).

\subsection{Reconciling economic efficiency and cost recovery objectives}

The use of tariffs for managing water demand is based on the assumption that demand for water to some extent follows similar trends as other goods in the market: that is, prices guide the choice of how much to produce and how much to consume, and 
serve to balance supply and demand. According to standard economic theory, in the absence of externalities in the market, prices of goods should be set at marginal cost. The marginal cost is the cost of producing an additional unit of a good or service at each level of production, and is represented by the price at which the marginal cost curve intersects with the demand curve. Such a price is said to be economically efficient since it signals to buyers the financial and other costs they impose on society as a result of the consumption of the goods/services, and also ensures that buyers obtain the largest possible aggregate of benefits at the given cost (Barberán and Arbués, 2009).

Water services and other networked utilities are subject to many important externalities and do not entirely portray characteristics of pure market goods/services. They possess 'unique' characteristics that need to be considered while applying the marginal cost pricing theory. First, water supply services and other networked utilities are characterised by substantial fixed costs and economies of scale. Hence, in the short term, when there is adequate infrastructure capacity for the foreseeable future, marginal costs are typically substantially lower than average costs, and so tariffs based on short-run marginal costs alone would not ensure full cost recovery. Second, short-run marginal costs are usually unstable - for a fixed capacity, the marginal cost will increase in peak load periods, in unison with the shifting demand curve, as shown in Figures 1 and 2 (MJA, 2004).

Figure 1 shows the relationship between demand and average cost and marginal cost curves when the water supply infrastructure has spare capacity, shortly after it has been constructed. In the short term, capital costs do not vary and so marginal cost $\left(P_{\mathrm{M}}\right)$ includes only the variable cost of water supply. However, as the

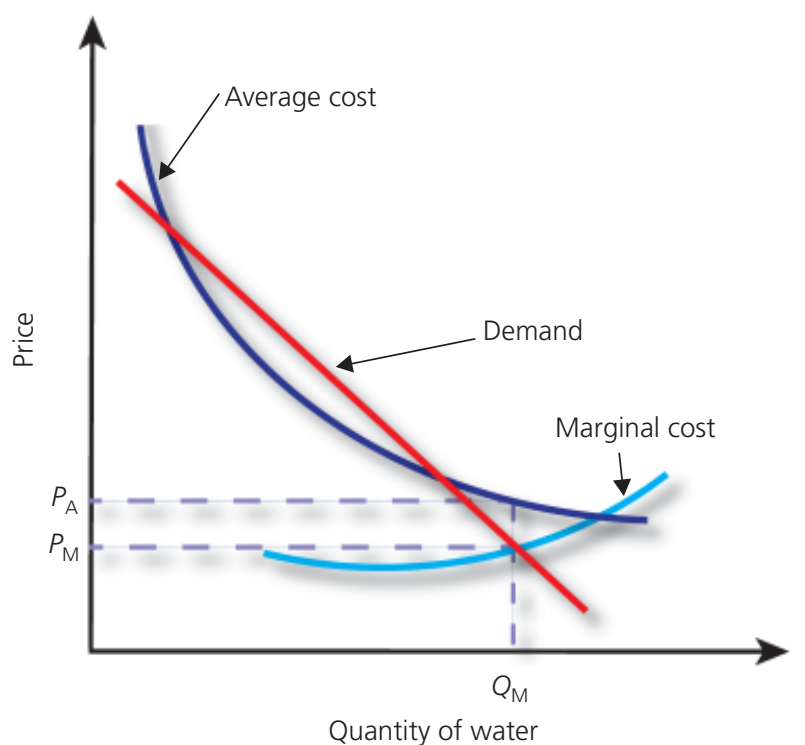

Figure 1. Cost curves of a fixed-capacity water supply system when there is spare capacity

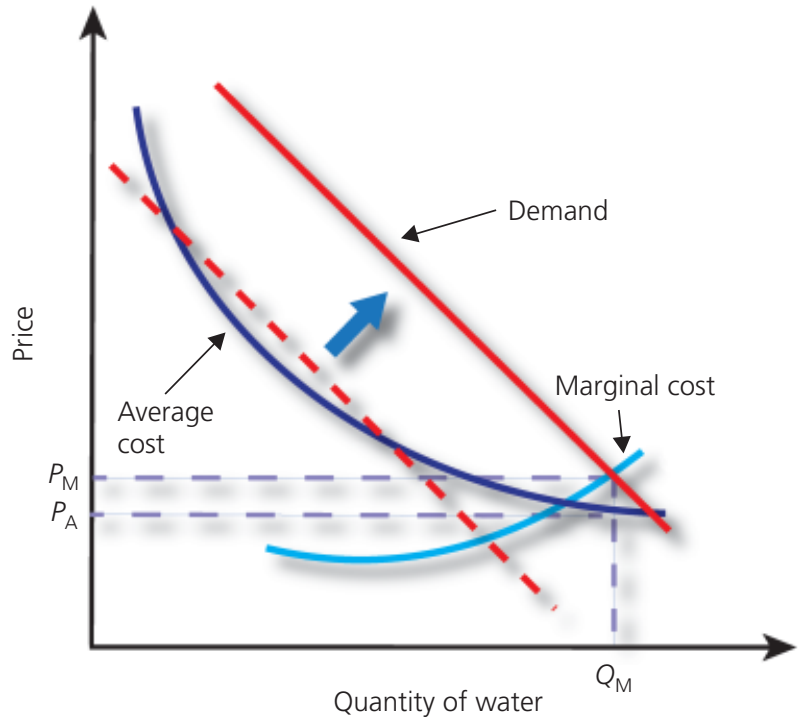

Figure 2. Cost curves for a fixed-capacity water supply system at peak load times

spare capacity of the water supply system is exhausted, effective demand for the water services increases and, during peak demand times, results in the demand curve shifting to the right, raising the marginal cost (Figure 2). Under these conditions, if the price is set at the marginal cost, $P_{\mathrm{M}}$ will be higher than the average cost and the revenue generated will be higher than full cost recovery. Hence, marginal costs are usually unstable during the short run and are difficult to estimate (MJA, 2004).

As urban populations grow, demand soon outstrips the capacity of the infrastructure, and utilities then need to plan for infrastructure extension, usually requiring the exploitation of new water resources. Typically, the inputs into the proceeding water supply project will be at higher costs than the previous project. The long-run marginal cost represents the marginal cost of capacity expansion over the long term and is always higher than the shortrun marginal cost. Recognition of the instability associated with short-run marginal costs has led to the preference of the long-run marginal cost method over the former. Nonetheless, there are choices to make on an appropriate planning horizon, in consideration of the fact that infrastructure investments in the water sector tend to be lumpy, longer term and may require building-in of substantial spare capacity. Another important consideration is the selection of a practical method for estimating long-run marginal costs that is easy to understand/explain and produces stable price schedules. One of the most commonly used methods for estimating long-run marginal costs in the water sector is the average incremental cost (AIC) methodology (Cantin et al., 2005; MJA, 2004; Whittington, 2003).

Economic efficiency is an important factor in the design of water tariffs. However, as shown in Figure 1, setting the price of water services at marginal cost price may not result in full cost 
recovery, even though the net value of water use is maximised. This situation occurs when average costs are above marginal costs at the optimum price, and will in turn lead to poor service levels, less organisational capacity and low level of sustainability of services. Furthermore, for lower income households, water usage will be less responsive to price changes and so the pricing signal will be less effective (MJA, 2004; Whittington, 2003).

To overcome these limitations and reconcile the objectives of economic pricing with full cost recovery, some utilities have used a two-part water rate. The first component is a volumetric charge to be paid for each unit of water consumed; this is computed according to the water supply system's marginal cost of providing the services. The second component of the tariff is a periodic fixed charge, unrelated to the metered water consumption, which covers any revenue shortfall. The simplest way to obtain this fixed charge is by dividing the total revenue shortfall by the number of connections. In practice, however, the revenue shortfall may be allocated among the utility's categories of customers, in line with other objectives for tariff setting such as social fairness and universal service coverage (Barberán and Arbués, 2009).

\subsection{Examples of tariff structures commonly applied for WDM}

Given the need to strike a balance between the multiple objectives described in Section 2.1, it is not practical for water utilities to aim for tariff structures that are perfectly economically efficient. A reasonable goal for many water utilities is to design and implement water tariffs that are as efficient as possible, given the business environment. One of the ways of measuring the economic efficiency of a tariff structure is the proportion of customers whose last unit of consumption is priced at the longrun marginal cost of water. In line with the objective of horizontal and vertical equity, common practice is to assign customers into categories that are based on demand and supply characteristics, and then develop the tariff structure based on these categories (Barberán and Arbués, 2009; Chesnutt et al., 1997).

As explained in Section 2.2, for a water-conserving tariff to also achieve the important objective of cost recovery, it will certainly have fixed periodic charges, which are unrelated to the amount of water consumed. These charges are variously termed customer charges, minimum charges, service charges, system development charges or access fees. Designing a water-conserving tariff involves balancing the need for revenue stability (which the fixed charges can enhance) and conservation-oriented pricing (which the variable charges can enhance). Long-term marginal costs are usually higher than short-term (operating) costs and so, usually, when the variable charge is set according to the long-run marginal costs and fixed charge to the fixed costs, the utility will collect revenues that exceed incurred costs. When the variable charges are much higher than the fixed charges, the issue of revenue stability crops up - when sales rise, revenues will rise more quickly than costs, but will fall more quickly in periods of low sales. Hence there is a need to find an optimum balance between the fixed and variable charges of a water tariff structure (Chesnutt et al., 1997; MJA, 2004). For utilities in developing countries where one of the key objectives of tariff structures is enhancement of social equity, it may be necessary to have stepped levels of fixed monthly charges in favour of the poor and/or vulnerable in society.

There are three commonly used types of variable rates for enhancing water conservation. For reasons of simplicity, many utilities implement uniform variable rates, by which the same unit price applies for all categories and quantity of water use. Figure 3 shows a graphical representation of a uniform volume rate. Uniform rates are easy to administer and conform to notions of equity and fairness. A variation that could further enhance the objective of social fairness and poverty alleviation is discriminating uniform rates by customer class. Although the extent to which uniform rates are water conserving may be contested, it is recognised that they perform better than decreasing block rate tariff or tariffs composed of only fixed charges (Barberán and Arbués, 2009; Chesnutt et al., 1997).

An increasing block tariff in which the applicable unit price increases for higher use tiers (see example shown in Figure 4) is perceived to be the most conservation-oriented price structure (Chesnutt et al., 1997). However, economists do not recommend charging different prices for water that has the same value, as this promotes economic inefficiency. Furthermore, the often soughtafter main objective of promoting social equity and fairness in developing countries may not be achieved by increasing block tariffs in contexts where poor households do not have individual house connections, but access water services through public standpipes and/or group connections (Boland and Whittington, 2000). The strongest argument in favour of the increasing block tariff structure is that it allows service providers to charge

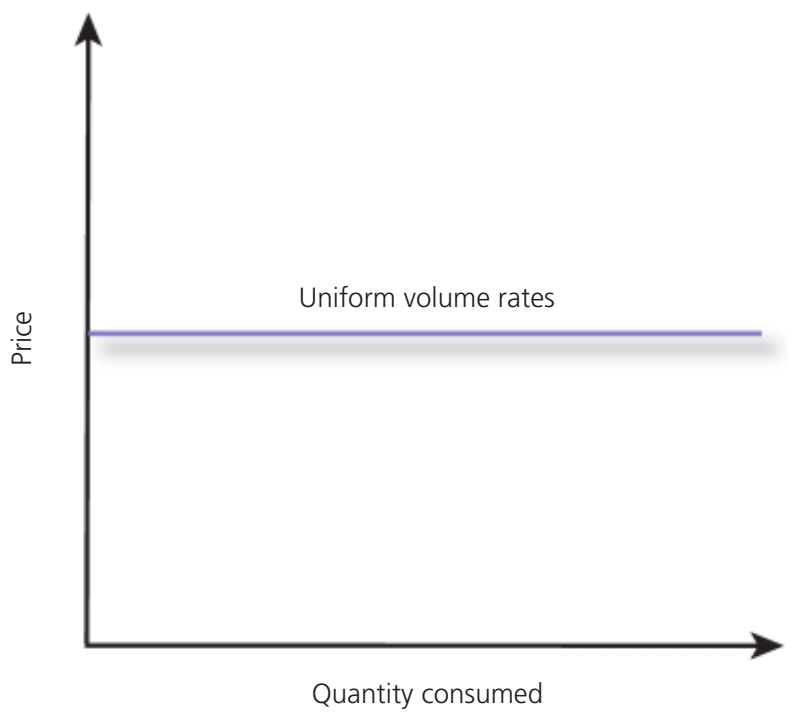

Figure 3. Graphical representation of a uniform volume rate 


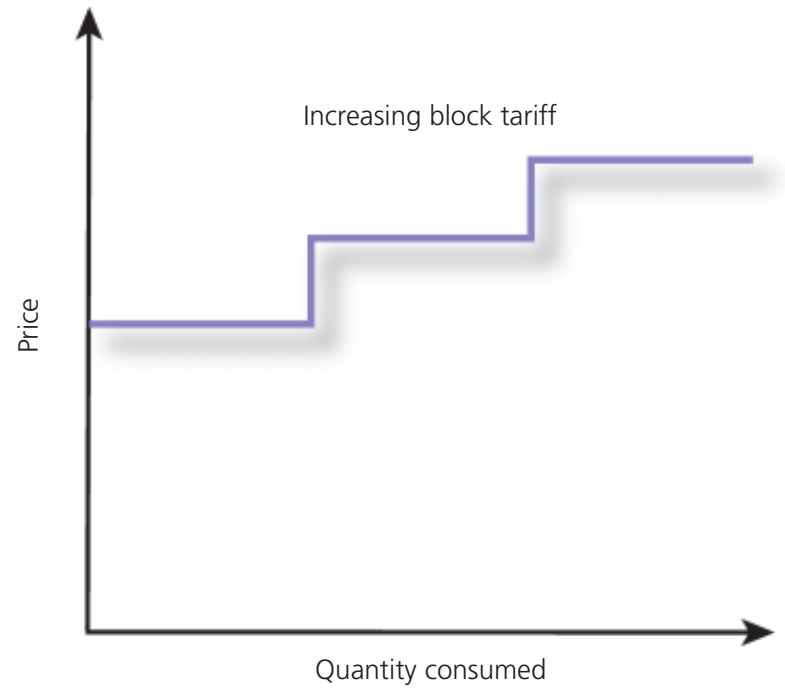

Figure 4. Graphical representation of an increasing block tariff

economically efficient prices to more customers than would otherwise be possible and, at the same time, addresses revenue sufficiency for the service provider (Chesnutt et al., 1997). Furthermore, increasing block tariffs are more likely to differentiate households that have more 'luxurious' water demands such as swimming pools and flower garden irrigation.

Some utilities, mainly in temperate regions, use seasonal tariff structures to cope with varying demand over the year. Most seasonal tariff structures have two demand periods - the peak period during the summer hotter/dryer period and the rest of the year, as shown in Figure 5. The seasonal tariff structure sends out important price signals about the cost of system expansion and promotes efficient water use amidst increased demand and/or water scarcity periods. The peak seasonal rates are designed to be

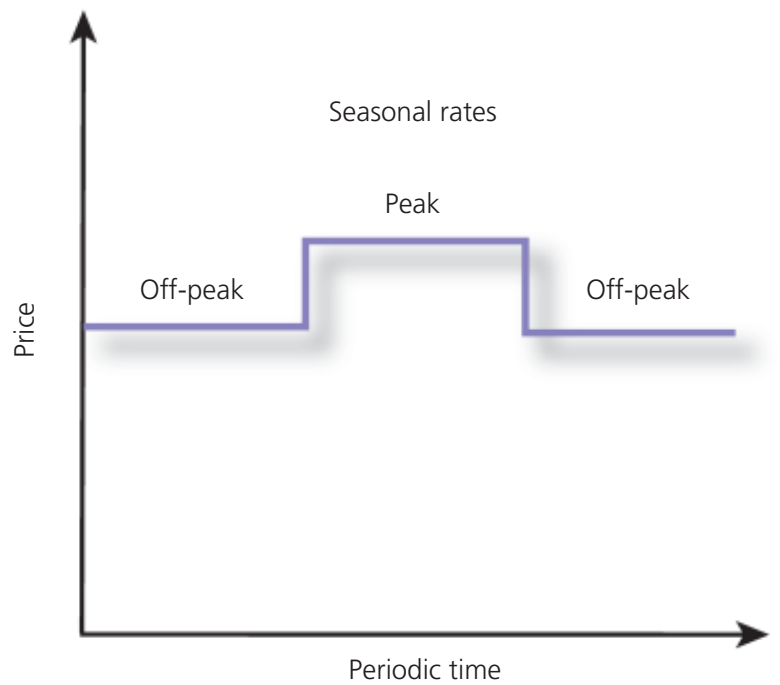

Figure 5. Graphical representation of a seasonal tariff structure close to the long-run marginal cost of water. For instance, since 2010, the rates for Southern Water Company in the UK are increased by $6 \%$ of the standard rate during June to September and come down by $2 \%$ during the period October to April every year. An alternative structure is to charge an increasing block tariff during the peak demand season (Chesnutt et al., 1997).

\section{Case study: Zaragoza, Spain}

Zaragoza is a city located in the River Ebro basin of northeastern Spain. In 2008, Zaragoza's population was 682300 . Prior to an extended drought that lasted up to 1995, water prices set by Zaragoza city council (AYTO), the water service provider, were mainly guided by financial and political objectives. The tariff structure comprised a fixed fee and a volumetric-based rate, which generated enough revenue to cater for a politically acceptable part of the costs of providing water services (Arbués and Villanúa, 2006). The monthly fixed fee was based on the street category where the building was located, which mainly depended on the length/width of the street and whether there were any commercial enterprises. The volumetric rates were categorised into four blocks, as shown in Table 1.

The tariff structure shown in Table 1 is progressive. For instance, if the consumption of consumer $\mathrm{X}$ was $20 \mathrm{~m}^{3}$ during the month, they would pay 527 pesetas (i.e. obtained by the addition of $(12 \times 6)+(25 \times 7)+(40 \times 7))$. However, there were quite a few properties that did not have consumption meters, which meant that the service provider would sometimes rely on estimated consumption. Furthermore, as can be seen in Table 1, there was no differentiation between domestic and non-domestic tariffs. This tariff structure did not encourage water conservation and so was found to be unsuitable during the extended drought period.

In 1995, in response to changes to the extended drought, AYTO initiated a long-term programme to reform the tariff. The tariff reform process was guided by findings of an econometric study carried out by the University of Zaragoza between 1996 and 2004. The key findings of this study were

- responsiveness of demand to price: the average price elasticity of demand was $-0 \cdot 0811$

Consumption:

Price: pesetas $/ \mathrm{m}^{3 a}$

$\mathrm{m}^{3}$ per property per month

$\begin{array}{ll}0-6 & 12 \\ >6,<13 & 25 \\ >13,<35 & 40 \\ >35 & 56\end{array}$

a The Spanish peseta was replaced by the Euro in 2002 at an exchange rate of 166.4 pesetas to $1 €$.

Table 1. Zaragoza variable tariff in 1993 (Lucea, 2010) 
- responsiveness of demand to income: the average income elasticity of demand was 0.7919

- the average elasticity of water consumption with respect to family size was 0·4794 (Arbués and Villanúa, 2006).

Other findings were that every household required an average basic minimum amount of $3.5 \mathrm{~m}^{3}$ per month to maintain the common good in the home, while each resident required additional $2.5 \mathrm{~m}^{3}$ of water per month, which decreased with household size, along economies of scale. Hence it was concluded that $18.5 \mathrm{~m}^{3}$ per household per month would meet the average requirements of households with up to six members.

AYTO redesigned the tariff structure to make it more water conserving, in line with the findings of the econometric study. The new tariff structure has been in operation since 2005, and price levels are regularly adjusted to conform to inflation rates. Table 2 presents the 2009 tariff structure for household size of up to six people; the table shows that, whereas consumption in blocks 1 and 2 attracts some subsidies, the price levels in block 3 cover full supply costs. This is a progressive tariff structure, similar to its predecessor. In order for households with more than six people to benefit from these subsidies, there is provision for them to be charged on a special tariff rate, after their claims have been verified by the responsible utility staff. Other categories of people that benefit from special tariffs are the unemployed, the sick and the poor.

Furthermore, AYTO has been offering economic incentives to households that reduce their consumption rates. If households

\begin{tabular}{llc}
\hline Consumption: & \multicolumn{2}{c}{ Rate: $€ / \mathrm{m}^{3}$ water } \\
$\mathrm{m}^{3}$ per household per month & Water & Sewerage \\
\cline { 2 - 3 } & & \\
\hline Block 1: $<6$ & 0.16 & 0.17 \\
Block 2: $>6,<18.5$ & 0.39 & 0.41 \\
Block 3: $>18.5$ & 0.78 & 0.82
\end{tabular}

Table 2. Typical 2009 Zaragoza variable water tariff (Lucea, 2010) reduced their consumption by at least $40 \%$ in the first year of joining the scheme, they were entitled to a $10 \%$ discount on their bill. In subsequent years, they were expected to reduce consumption by $10 \%$ per annum in order for them to benefit from a similar price rebate. Table 3 shows the number of households that benefited from the economic incentives from when the scheme started, in 2002, to 2006.

Table 3 shows that some households had the capacity to continuously make savings in subsequent years. For instance, of the 1708 households that reduced their consumption by $40 \%$ in 2002, 375 of these made a further $10 \%$ reduction in 2003 . A further $10 \%$ saving was achieved by 66 households in 2004, two households in 2005 and one household in 2006. As can be seen from column 2 of the table, the scheme was embraced by an increasing number of households, which contributed to overall reduction in water consumption in Zaragoza in subsequent years.

The economic instruments described above complemented other activities carried out as part of a long-term programme implemented by a partnership of key stakeholder organisations in Zaragoza aimed at improving efficiency of urban water use in the city (Kayaga et al., 2008). This programme, implemented between 1997 and 2008, used a combination of measures and instruments to effect behavioural change among end-users and encourage them to make structural changes in their fixtures and appliances, which resulted in positive changes in water use efficiency. Although the city's population increased from 606069 in 1997 to 682283 by 2008 (an increase of over 12\%), overall water consumption reduced from 84.8 to 61.5 million $\mathrm{m}^{3}$ - a reduction of $27 \%$ (AYTO, 2009). A survey conducted in Zaragoza showed that the adoption of water-efficient devices made a significant contribution to water conservation. Behavioural change, which was largely influenced by the economic instruments (i.e. tariff redesign and economic incentives), produced a more significant contribution to water conservation (Edo and Soler, 2004).

\section{Case study: Kampala, Uganda}

Kampala, the capital city of Uganda, has an estimated population of 1.35 million, $45 \%$ of whom live in low-income

\begin{tabular}{lcccrr}
\hline \multirow{2}{*}{ Start year } & $\begin{array}{c}\text { Households } \\
\text { with new } \\
\text { commitment }\end{array}$ & \multicolumn{4}{c}{ Further subsequent savings of 10\% in the year } \\
\cline { 3 - 6 } & 2003 & 2004 & 2005 & 2006 \\
\hline 2002 & 1708 & 375 & 66 & 2 & 1 \\
2003 & 27741 & & 5331 & 487 & 123 \\
2004 & 24331 & & & 2956 & 721 \\
2005 & 27929 & & & & 4635 \\
2006 & 33274 & & & &
\end{tabular}

Table 3. Number of households benefiting from economic

incentives (Lucea, 2010) 
informal settlements (BCA, 2004). The water and sewerage services in Kampala and 21 other major urban areas in the country are provided by the National Water and Sewerage Corporation (NWSC), a corporate public-owned utility. The level and quality of water in Lake Victoria, from which NWSC draws its supplies for Kampala and a few other major towns, have deteriorated in the past few years, mainly due to the effects of climate change and rapid urbanisation respectively. This has necessitated continuous infrastructure investment.

The objective of this study was to investigate how waterconserving tariffs could be used as an economic instrument to encourage current household consumers to conserve water in their premises and hence reduce the pressure placed on the infrastructure and water resources in Kampala. This study used billing data and basic socio-economic data for Kampala to develop a Microsoft Excel based model for optimising a waterconserving tariff structure while also aiming to achieve appropriate cross-subsidies between income groups in a socially equitable manner. Monthly household billing datasets were obtained for 71851 households for the period July 2006 to June 2007, which, after processing, produced 54024 useable datasets. These were arranged in hierarchical order based on customer reference numbers, and a 5\% random sample was drawn, yielding 2701 households.

The following socio-economic attributes for Kampala were adopted from previous studies.

- Average household size of five, obtained from the Uganda national household survey 2005/2006 (UBOS, 2006).

- Per capita water consumption estimates for three income categories (high, medium and low) obtained from a consultancy study by Beller Consult and Associates (BCA, 2004).

- Estimated (2004) income ranges for customers of NWSC in Kampala obtained from a study on water service connection charges and costs (Kayaga and Franceys, 2007) and adjusted by Uganda's national economic growth rate of $6 \%$.
Data on price elasticity of demand for Kampala could not be found and so, through parallel surveying, the city of Cape Town was identified as the closest match. Estimated figures for price elasticity were reported in a study by Jansen and Schulz (2006) and these matched with data obtained from Kampala, as shown in Table 4.

The following key assumptions were taken into consideration.

Each household uses its own water service connection, with no sharing between households.

- Average household size is the same across income categories in Uganda's urban areas (i.e. five people per household).

- Domestic water use patterns remain the same over the modelling period.

- Annual price adjustments of $6 \%$, indexed to inflation rates, have negligible effect on demand for water.

- Affordability to pay for water services conforms to the World Bank's rule of thumb of not more than $3 \%$ of household income (Komives et al., 2005).

The model, which optimised price levels for different income groups according to the affordability criteria (above), was based on the following equation for price elasticity of demand $\left(E_{\mathrm{d}}\right)$

$$
Q_{2}=\left[1+\left(P_{2} / P_{1}-1\right) E_{\mathrm{d}}\right] Q_{1}
$$

in which $Q_{1}$ is the initial quantity of water consumed when the price is $P_{1}$ and $Q_{2}$ is the adjusted quantity consumed when the price is changed to $P_{2}$. At the time of the study, NWSC charged a uniform rate of 1213 Uganda shillings (UGX) per cubic metre for all household consumption (i.e. $P_{1}=1213$ for all three categories).

Table 5 shows key changes in consumption patterns that would be imposed by the new increasing block tariff provided by the model. If households spend $3 \%$ of their income on water services, then the increasing block tariff structure will have three blocks, in line with the three income categories, and the price levels will change as shown in row 3 of Table 5 . The price for block 1 will reduce by

\begin{tabular}{lcccc}
\hline $\begin{array}{l}\text { Income } \\
\text { category }\end{array}$ & $\begin{array}{c}\text { Estimated } \\
\text { income: } \\
\text { o00 UGX }\end{array}$ & $\begin{array}{c}\text { Average per } \\
\text { capita } \\
\text { consumption: } \\
\text { I }\end{array}$ & $\begin{array}{c}\text { Monthly } \\
\text { household } \\
\text { consumption: } \\
\mathrm{m}^{3}\end{array}$ & $\begin{array}{c}\text { Estimated price } \\
\text { elasticity of } \\
\text { demand }\end{array}$ \\
\hline High & $>1403$ & 144 & $>22$ & -0.23 \\
Middle & $503-1403$ & 100 & $11-22$ & -0.32 \\
Low & $<503$ & 40 & $<11$ & -0.99 \\
\hline
\end{tabular}

a 2500 UGX $=1$ US\$. 


\begin{tabular}{|c|c|c|c|c|}
\hline & $\begin{array}{c}\text { Block } 1 \\
<11 \mathrm{~m}^{3} / \text { month }\end{array}$ & $\begin{array}{c}\text { Block } 2 \\
11-22 \mathrm{~m}^{3} / \text { month }\end{array}$ & $\begin{array}{c}\text { Block } 3 \\
>22 \mathrm{~m}^{3} / \text { month }\end{array}$ & Average \\
\hline Proportion of households (existing tariff): \% & 29 & 41 & 29 & - \\
\hline Proposed tariff: UGX/m³ & 1190 & 1372 & 1914 & 1314 \\
\hline Change in tariff: \% & -2 & 13 & 58 & 8 \\
\hline Proportion of households (proposed tariff): \% & 29 & 49 & 22 & - \\
\hline Increase in per capita consumption in each block: \% & 0 & +4 & -21 & -20 \\
\hline Reduction in consumption in each block: $\mathrm{m}^{3} / y e a r$ & -15812 & 1246152 & 3765414 & - \\
\hline Water allocation: \% & 14 & 48 & 38 & - \\
\hline
\end{tabular}

Table 5. Outputs of the tariff model for Kampala

(Motoma, 2007)

$2 \%$, while prices for those in blocks 2 and 3 will increase by $13 \%$ and $58 \%$ respectively. As a result, about $8 \%$ of households will reduce their water consumption and migrate from block 3 to block 2. Block 1 will remain almost constant, at about $29 \%$. The movements between consumption blocks will thus result in water savings. Row 5 of the table shows that, whereas per capita consumption rates for block 3 would reduce by $21 \%$ as a result of the price increase, per capita consumption rates in blocks 1 and 2 would not change significantly.

This tariff structure would enhance allocative efficiency, given that water consumed by the high-income group would reduce from $55 \%$ to $38 \%$. Furthermore, use of this tariff structure would result in overall water savings worth $2535074 \mathrm{~m}^{3}$ while increasing revenue collection for the service provider by 1.7 billion UGX (US\$ 0.68 million) per year. The savings made could be utilised to expand services to low-income unplanned settlements in Kampala, where most households are not directly connected to the city's water reticulation network, partly due to inadequate water in the supply system. Densification of connections in lowincome settlements, removing 'barriers to entry' in the connection process and recognising group connections would reduce the negative effect of an increasing block tariff to the urban poor (Kayaga and Franceys, 2007).

\section{Conclusions}

Water demand management strategies could be used in the short term to plug supply-demand deficits currently existing in many cities of developing countries and promote sustainable urban water management in the city of the future. Economic instruments, particularly tariff structures, when appropriately designed, have the potential of encouraging water conservation in households. However, there will always be trade-offs between achieving economic efficiency and other important objectives such as revenue adequacy for the service provider and affordability for low-income households.

This paper has described an increasing block tariff structure adopted after an extended drought in Zaragoza, Spain, which contributed to significant water conservation in households.
Applying similar econometric principles, a tariff structure was modelled for Kampala, Uganda, which is shown to not only conserve water, but also to increase revenue and improve allocation efficiency of water between various income groups. The effectiveness of the tariff would depend strongly on the validity and reliability of the socio-economic data used to design the tariff. This paper demonstrates that WDM concepts, which have increasingly gained prominence in some developed countries, can be adapted to provide benefits in low-income countries.

\section{Acknowledgements}

A shorter version of this paper was presented at the 2nd International Conference on Advances in Engineering and Technology, in Entebbe, Uganda (31 January - 1 February 2011). The authors would like to acknowledge the work of Mr Ramogodi I. Motoma, who carried out the Kampala case study as part of his MSc dissertation. The authors are also grateful to Mr Rod Shaw for his assistance in converting the line drawings to an acceptable format. The Zaragoza case study was carried out under the auspices of the EU-funded Switch Project, under the FP6 Programme.

\section{REFERENCES}

Arbués F and Villanúa I (2006) Potential for pricing policies in water resource management: estimation of urban residential water demand in Zaragoza, Spain. Urban Studies 43(13): 2421-2442.

AYTO (Zaragoza Ayuntamiento) (2009) Zaragoza in SWITCH Project. AYTO, Zaragoza, Spain, unpublished report.

Barberán R and Arbués F (2009) Equity in domestic water rates design. Water Resources Management 23(10): 2101-2118.

BCA (Beller Consult and Associates) (2004) Sanitation Strategy and Master Plan for Kampala City. BCA, Kampala, Uganda.

Boland JJ and Whittington D (2000) The political economy of water tariff design in developing countries: increasing block tariffs versus uniform price with rebate. In The Political Economy of Water Pricing Reforms (Dinar A (ed.)). Oxford University Press and World Bank, Washington, DC, USA.

Cantin B, Shrubsole D and Ait-Ouyahia M (2005) Using economic instruments for water demand management: introduction. Canadian Water Resources Journal 30(1): 1-10. 
Chesnutt TW, Beecher JA, Mann PC et al. (1997) Designing, Evaluating, and Implementing Conservation Rate Structures. A Handbook for the Californian Urban Water Conservation Council. A\&N Technical Services, Inc., Santa Monica, CA, USA.

Edo VV and Soler MF (2004) Saragossa, 50 examples of efficient water use in the city. Water Science and Technology: Water Supply 4(3): 111-122.

Jansen A and Schulz C (2006) Water Demand Management and the Urban Poor: A Study of the Factors Influencing Water Consumptions Among Households in Cape Town, South Africa. University of Tromso, Norway, Working Series in Economics and Management No. 02/06.

Kayaga S (2011) Introduction to water demand management. In Water Demand Management in the City of the Future: Selected Tools and Instruments for Practitioners (Kayaga S and Smout I (eds)). WEDC, Loughborough University, Loughborough, UK, pp. 8-23.

Kayaga S and Franceys R (2007) Costs of urban utility water connections: excessive burden to the poor. Utilities Policy 15(4): 270-277.

Kayaga SM, Sainctavit L, Smout IK and Bueno V (2008) Partnerships for enhancing the water-saving culture in Zaragoza, Spain. Proceedings of IWA World Water Congress, Vienna, Austria. International Water Association (IWA), London, UK.

Komives K, Foster V, Halpern J and Wodon Q (2005) Water, Electricity, and the Poor: Who Benefits from Utility Subsidies? World Bank, Washington, DC, USA.
Lucea JG (2010) Criteria Used to Design the Water Tariff. AYTO, Zaragoza, Spain, unpublished internal document.

MJA (Marsden Jacob Associates) (2004) Estimation of Long Run Marginal Cost (LRMC). MJA, Camberwell, VIC, Australia, Report prepared for Queensland Competition Authority.

Motoma RI (2007) Modelling a Water Conserving Tariff for the City of Kampala. MSc dissertation, Loughborough University, Loughborough, UK.

Savenije H and van der Zaag P (2002) Water as an economic good and demand management: paradigms with pitfalls. Water International 27(1): 98-104.

Stern N (2007) The Economics of Climate Change: The Stern Review. Cambridge University Press, Cambridge, UK.

Turner A, Willets J, Fane S et al. (2006) Planning Our Future Urban Water Resources: A Guide to Demand Management in the Context of Integrated Resource Planning. Institute of Sustainable Futures, University of Technology, Sydney, Australia.

UBOS (Uganda Bureau of Statistics) (2006) Uganda National Household Survey 2005/2006. UBOS, Kampala, Uganda.

UN-Habitat (2009) Planning Sustainable Cities: Global Report on Human Settlements. UN-Habitat, Nairobi, Kenya.

White SB and Fane SA (2001) Designing cost effective water demand management programs in Australia. Water Science and Technology 46(6-7): 225-232.

Whittington D (2003) Municipal water pricing and tariff design: a reform agenda for South Asia. Water Policy 5(1): 61-76.

Whittington D and Boland J (2001) Reflections on Water Pricing and Tariff Design, unpublished presentation.

\section{WHAT DO YOU THINK?}

To discuss this paper, please email up to 500 words to the editor at journals@ice.org.uk. Your contribution will be forwarded to the author(s) for a reply and, if considered appropriate by the editorial panel, will be published as a discussion in a future issue of the journal.

Proceedings journals rely entirely on contributions sent in by civil engineering professionals, academics and students. Papers should be 2000-5000 words long (briefing papers should be 1000-2000 words long), with adequate illustrations and references. You can submit your paper online via www.icevirtuallibrary.com/content/journals, where you will also find detailed author guidelines. 